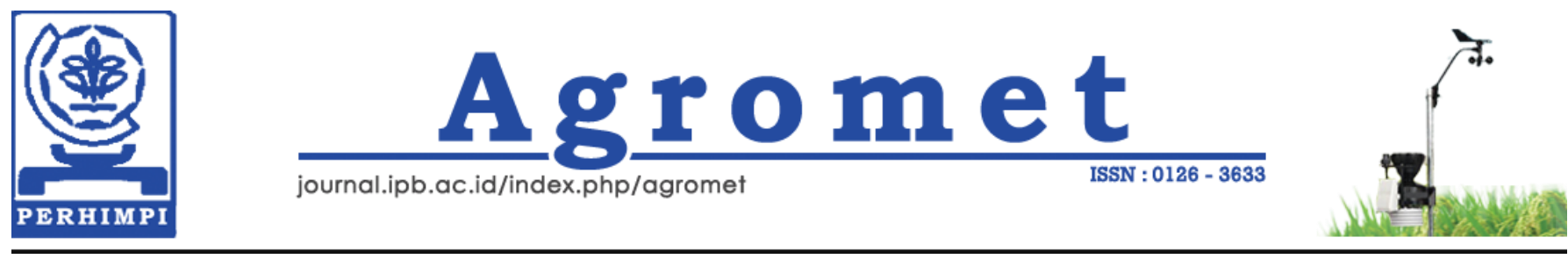

\title{
Kelembaban Iklim Mikro Persemaian dan Produksi Berbagai Varietas Melon (Cucumis melo L.) Unggul Baru di PKHT Tajur II
}

Microclimate Humidity in Nursery and Production Various Melon (Cucumis melo L.) Genotypes in PKHT Tajur II

\section{Dirgha Ahdiansyah Surya Adinegara ${ }^{1}$, Rini Hidayati $^{2 *}$ dan Perdinan ${ }^{2}$}

${ }^{1}$ Sabisa Farm, Jalan Sindang Barang, Loji, Bogor Barat-Kota Bogor

${ }^{2}$ Departemen Geofisika dan Meteorologi, Fakultas Matematika dan Ilmu Pengetahuan Alam, Institut Pertanian Bogor Gedung FMIPA Jl. Meranti Wing 19 Lv.4 Kampus IPB Dramaga Bogor 16680

\author{
ARTICLE INFO \\ Article history: \\ Received 19 November 2016 \\ Received in revised from 17 February \\ 2017 \\ Accepted 1 March 2017
}

doi: 10.29244/j.agromet.31.1.31-42

Keywords:
Genotype
Melon
Relative humidity
Leaf area index
Radiation interception

\section{PENDAHULUAN}

Kebutuhan komoditas hortikultura di Indonesia kian meningkat seiring dengan pertambahan jumlah penduduk. Oleh sebab itu peningkatan produksi pertanian diperlukan terutama untuk komoditas hortikultura (Arifin, 2013; Hutabarat et al., 2012; Nashih et al., 2016; Yekti et al., 2015). Melon adalah komoditas hortikultura yang digemari masyarakat Indonesia karena rasa yang manis, memiliki tekstur daging yang lembut, dan warna daging buah yang beragam (Falah et al., 2014; Sharma et al., 2014; Silveira et al., 2013).

\begin{abstract}
A B S T R ACT
Micro-climatic conditions may affect the growth and productivity of different genotypes of melon farm. This study aims to assess the effect of different moisture conditions in the melon's nursery to the growth and production of different melon's genotypes. To observe the effect of moisture, we monitored agronomical (leaf-area index, plant height, fruit weight) and micro-meteorological (transpiration, radiation interception) parameters for two treatments i.e. without modification of moisture (control) and with modification of moisture for period August-November 2015 at the Experimental Garden of IPB in Tajur II-Bogor. Totally, twelve genotypes of melon were used in the study. We found that a transpiration rate was reduced under the control treatment. It appears that the humidity treatment has a greater effect on both measured parameters. The plant height during the germination phased was affected by the humidity treatment, which was confirmed by the two statistical tests (ANOVA and $t$-test). In addition, our results showed that the treatment had influenced the harvesting time. Under the control treatment, melon seems to have a shorter time to harvest (about 61-63 days after planting), but a lower fruit weight. On the other hand, the modified humidity resulted in a longer time to harvest (6871 days after planting) and a higher fruit weight. Further, with the treatment we found some genotypes that were potentially able to produce high yield, and some genotypes that were more resistant to dry conditions but they produced a relatively high yield.
\end{abstract}

Produksi melon di Indonesia cenderung meningkat sejak dasawarsa terakhir. Produksi buah melon tahun 2008 sebesar kurang dari 60,000 ton, sedangkan tahun 2013 meningkat mencapai lebih dari 120,000 ton (Ditjenhorti, 2014). Akan tetapi, peningkatan produksi tersebut tidak didukun goleh teknologi pembenihan yang memadai, sehingga Indonesia masih mengimpor benih melon dalam jumlah banyak. Hal ini membuka peluang bagi para pemulia tanaman untuk mendapatkan berbagai benih varietas unggul. Dalam melakukan pemuliaan benih melon perlu adanya karakterisasi untuk membentuk populasi dasar sehingga benih yang dihasilkan akan

\footnotetext{
* Corresponding author. rinihidayatigfm@gmail.com
} 
berkualitas (Ren et al., 2013; Singh et al., 2013) dan dapat mensubtitusi benih impor. Pemuliaan tanaman benih melon dapat dilakukan dengan membentuk varietas hibrida unggul. Melon hibrida yang diharapkan adalah yang berproduksi dan berkualitas tinggi.

Teknik untuk mendapatkan melon hibrida telah banyak dikenal dan dikuasai. Akan tetapi, kajian lingkungan terutama kondisi iklim mikro yang mendukung uji lapang varietas hibrida, untuk mendapatkan varietas melon hibrida unggul masih sangat jarang dilakukan. Unsur-unsur iklim yang berpengaruh terhadap perkembangan dan pertumbuhan tanaman adalah radiasi matahari (Kataria et al., 2014; Körner, 2015) dan suhu udara (Hatfield and Prueger, 2015; J. Lipiec et al., 2013; Sánchez et al., 2013). Faktor yang paling berpengaruh terhadap pertumbuhan tanaman adalah suhu udara dan panjang hari, sedangkan pada perkembangan tanaman (fenologi) hampir semua unsur iklim berpengaruh. Pengaruh unsur iklim terutama suhu udara terhadap fenologi tanaman (Cleland et al., 2007) dapat dijelaskan dengan thermal unit (day degrees atau heat unit) (Irmak et al., 2013; Molitor et al., 2014). Selain faktor termal, ketersediaan air juga sangat menentukan keberhasilan tanam (Claeys and Inzé, 2013; Killi et al., 2014; Moshelion et al., 2014).

Penelitian ini diharapkan akan membantu mengidentifikasi kondisi cuaca mikro yang mendukung produksi melon hibrida unggul. Penelitian ini bertujuan mempelajari pengaruh perbedaan kondisi kelembaban di sekitar tanaman melon saat persemaian dan hasil produksi beberapa genotipe tanaman melon.

\section{METODE PENELITIAN}

Bahan yang digunakan adalah 12 genotipe benih tanaman melon koleksi Pusat Kajian Hortikultura Tropika (PKHT) IPB, tray, media tanam (pupuk organik dan tanah). Data Iklim harian meliputi curah hujan, suhu udara maksimum dan minimum, $\mathrm{RH}$ dan radiasi dari Stasiun Klimatologi Baranangsiang FMIPA-IPB pada bulan Agusutus-November 2015.

Peralatan yang digunakan yaitu alat-alat pengolahan tanah, rumah semai, termometer bola basah dan kering, data logger (untuk mengukur suhu udara dan kelembaban, radiasi matahari), timbangan, dan meteran.

Penelitian ini menggunakan rancangan acak lengkap faktor tunggal. Jumlah satuan percobaan yang digunakan ada 24 tray, dalam 1 tray terdapat 72 lubang, 1 lubang berukuran $4 \mathrm{~cm} \times 4 \mathrm{~cm} \times 4 \mathrm{~cm}$ dan ukuran tray $54 \mathrm{~cm} \times 28 \mathrm{~cm} \times 6 \mathrm{~cm}$. Luas lahan yang digunakan saat pindah tanam sebesar $500 \mathrm{~m}^{2}$. Perlakuan yang diberikan yaitu, nomor Genotipe (P): P17, P26, P3, P19, P29, P2, P7, P5, P23, P27, P18, P25. Kondisi rumah semai (J): Rumah semai tanpa modifikasi kelembaban (J0) dan Rumah semai dengan modifikasi kelembaban (J1).

Rumah semai untuk dua perlakuan adalah satu rumah semai dengan kondisi kering/kelembaban rendah dan satu rumah semai dengan kondisi kelembaban tinggi (menggunakan terpal yang diisi dengan air untuk modifikasi kelembaban).

Pembenihan dilakukan dengan cara benih melon ditebarkan di kertas buram kemudian disiram air tujuannya untuk melembabkan benih untuk tumbuh akar, setelah tumbuh akar dipindahkan ke dalam lubang tray dan diberikan media tanam (pupuk organik dan tanah). Dalam rumah semai di tempatkan 12 tray dan 12 nomor genotipe melon dengan empat kali ulangan.

Dosis pupuk kandang yang digunakan adalah 15-20 ton ha-1, pupuk urea $250 \mathrm{~kg} \mathrm{ha}^{-1}, \mathrm{SP}-36450 \mathrm{~kg}$ $\mathrm{ha}^{-1}$, dan $\mathrm{KCl} 250 \mathrm{~kg} \mathrm{ha}^{-1}$. Dosis kapur pertanian (dolomit) adalah 2 ton ha-1, sedangkan jarak tanam yang digunakan adalah $60 \mathrm{~cm} \times 60 \mathrm{~cm}$.

Bibit melon yang siap untuk ditanam berumur 5-7 hari setelah semai. Batang tanaman mulai diikat pada ajir bambu setelah tanaman berumur sekitar 12 hari atau setelah memiliki 7 daun. Pemangkasan tunas dilakukan dari ruas ke-1 sampai dengan ruas ke- 8 dan di atas ruas ke- 11 dengan menyisakan satu helai daun. Setelah buah dari cabang ke-9 sampai ke-12 tumbuh kira-kira sebesar bola pingpong, dipilih satu buah yang terbaik untuk terus dipelihara sampai besar.

Panen dilakukan saat sebagian besar (80\%) tanaman menampakkan ciri ukuran buah yang menjadi besar dan warna buah yang menjadi kuning atau warna jalar menjadi cerah. Pemanenan dilakukan dengan cara mencabut tanaman lalu dikeringkan, kemudian bijinya dirontokkan.

Unsur-unsur iklim sekitar pertanaman pada masing-masing rumah semai yang diamati meliputi suhu udara dan kelembaban. Suhu udara dan kelembaban diukur menggunakan termometer bola basah dan kering pada tiap jam dari pukul 06:00 hingga 18:00 selama 10 hari setelah semai (HSS).

Pengukuran setelah semai menggunakan data logger (suhu udara, kelembaban dan radiasi matahari). Pengukuran tinggi tanaman dilakukan tiap hari dari 0 HSS sampai tanaman dapat dipindahkan dari rumah semai. Setelah pindah tanam, pengukuran tinggi tanaman dilakukan tiap 3 hari sejak 10 hari setelah tanam (10 HST). Pengukuran luas daun dilakukan mulai dari 1 MST hingga 8 MST. Tanaman contoh (satu tanaman) per genotipe diambil tiap minggu dilakukan 
mulai dari 6 MST sampai 9 MST. Tanaman contoh tersebut dikeringkan dengan menggunakan oven selama 4 hari pada suhu $100^{\circ} \mathrm{C}$.

\section{HASIL DAN PEMBAHASAN}

\section{Tinggi tanaman}

Tinggi tanaman melon pada 12 genotipe yang diuji bertambah dengan cepat pada fase perkecambahan dimulai 0 HSS sampai 9 HSS. Dari 12 genotipe diperoleh rata-rata tinggi tanaman dengan perlakuan modifikasi kelembaban lebih tinggi dibandingkan dengan perlakuan tanpa modifikasi kelembaban.

Pengujian beda tinggi tanaman pada fase perkecambahan dengan mengunakan ANOVA pada taraf nyata $5 \%$ pada 12 genotipe tanaman melon yang diuji menunjukkan adanya pengaruh perlakuan pada tinggi tanaman. Pengujian menggunakan uji T pada taraf nyata $95 \%$ menunjukkan adanya pengaruh perlakuan pada beberapa genotipe. Dari hasil uji T genotipe P17, P26, P3, P29, P2, P23 dan P25 terpengaruh oleh perlakuan (Tabel 1). Tingginya kelembaban membuat ketersediaan air di dalam tanah tetap tinggi sehingga penggunaan air atau laju transpirasi lebih tinggi dan pertumbuhan tinggi tanaman lebih baik. Kekurangan air secara umum cenderung menghambat pertumbuh-an tanaman.

Dalam proses fotosintesis, $\mathrm{CO}_{2}$ masuk dari atmosfer ke dalam daun melalui stomata. Sebaliknya, uap air akan keluar dari dalam daun ke atmosfer juga melalui stomata yang lajunya sama dengan laju transpirasi. Laju transpirasi atau penggunaan air lebih rendah pada kondisi kering. Bila persediaan air tanah rendah, maka tanaman akan menghemat penggunaan air melalui penutupan stomata atau meningkatkan tahanan stomata, sehingga $\mathrm{CO}_{2}$ yang masuk kedalam daun menurun dan mengakibatkan menurunnya fotosintesis. Hal tersebut terjadi pada rumah semai dengan perlakuan tanpa modifikasi kelembaban.

Tabel 1 Nilai statistika tinggi tanaman (rata-rata, stdev dan selisih) dari 12 genotipe tanaman melon pada fase perkecambahan (0-9 HST). Unit dalam satuan cm.

\begin{tabular}{cccccc}
\hline \multirow{2}{*}{ Genotipe } & \multicolumn{2}{c}{$\begin{array}{c}\text { Tanpa modifikasi } \\
\text { kelembaban }\end{array}$} & \multicolumn{2}{c}{$\begin{array}{c}\text { Modifikasi } \\
\text { kelembaban }\end{array}$} & $\begin{array}{c}\text { Selisih tinggi } \\
\text { tanaman antar } \\
\text { perlakuan }\end{array}$ \\
\cline { 2 - 4 } & Rata-rata & Stdev & Rata-rata & Stdev & 0.8 \\
P 17 & 4.2 & 0.4 & 5 & 0.36 & 0.6 \\
P26 & 3.5 & 0.4 & 4.1 & 0.4 & 0.3 \\
P3 & 5. & 0.7 & 5.3 & 0.4 & 0.6 \\
P19 & 5.4 & 0.6 & 6. & 0.4 & 1.2 \\
P29 & 3.3 & 0.3 & 4.5 & 0.6 & -0.4 \\
P2 & 5.2 & 0.6 & 4.8 & 0.4 & 2.2 \\
P7 & 3.1 & 0.8 & 5.3 & 0.6 & 1.0 \\
P5 & 2.7 & 0.5 & 3.7 & 0.2 & -0.1 \\
P23 & 5.3 & 0.5 & 5.2 & 0.4 & 0.4 \\
P27 & 4.5 & 0.4 & 4.9 & 0.7 & 0.3 \\
P18 & 6.2 & 0.8 & 6.5 & 0.7 & 1.5 \\
P25 & 2.9 & 0.3 & 4.4 & 0.3 & 0.7 \\
\hline Rata-rata & 4.3 & \multicolumn{5}{c}{} \\
\hline
\end{tabular}

Keterangan: Huruf cetak tebal menandakan genotipe tersebut terpengaruh oleh perlakuan pada periode HST yang berbeda-beda. Huruf digaris bawahi menandakan genotipe memiliki nilai tinggi tanaman tertinggi. Hasil positif (+) pada selisih tinggi tanaman antar perlakuan menunjukkan pemberian perlakuan menambah tinggi tanaman, sedangkan hasil negatif (-) menunjukkan pemberian perlakuan tidak menambah tinggi tanaman.

\section{Berat kering total per-tanaman melon}

Berat kering total tanaman dari 12 genotipe yang diuji mengalami pertumbuhan seiring dengan pertambahan umur tanaman. Peningkatan berat kering pada tanaman disebabkan karena tanaman melon terus berfotosintesis dan membentuk bahan kering yang kemudian dialokasikan ke bagian-bagian tanaman.

Fase vegetatif berlangsung hingga $6 \mathrm{MST}$, alokasi berat kering sebagian besar menuju batang dan daun. Alokasi berat kering mulai menuju kearah pembentukan biji pada saat fase generatif (7-8 MST).

Pada saat 8 MST tanaman melon dari 12 genotipe yang di uji menunjukkan bahwa sekitar $50 \%$ berat kering hasil fotosintesis dialokasikan untuk pertumbuhan biji, sedangkan alokasi berat kering ke daun dan batang sekitar 15\% dan 35\%. Pada tanaman genotipe P29 tanpa modifikasi kelembaban memiliki bobot kering total tertinggi yaitu sebesar 99 gr (Gambar 1). 
Adinegara et. al./Agromet 31 (1): 31-42, 2017

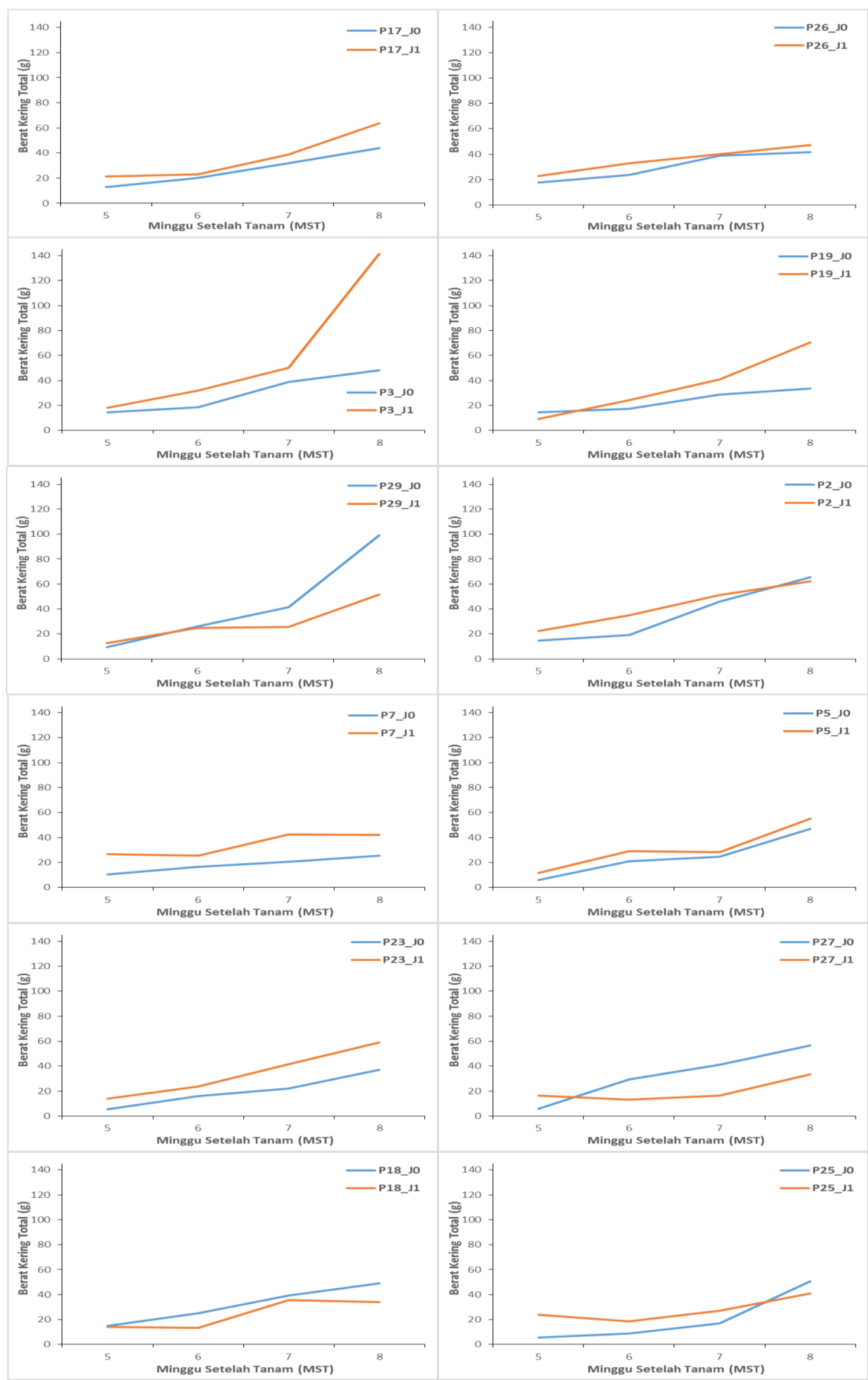

Gambar 1 Bobot kering total rata-rata tanaman (g) dari 12 genotipe pada kondisi tanpa modifikasi kelembaban dan kondisi modifikasi kelembaban. 
Tanaman genotipe P3 dengan modifikasi kelembaban memiliki bobot kering total tertinggi yaitu sebesar $142 \mathrm{gr}$ (Gambar 1). Hasil fotosintesis yang dihasilkan dari tiap genotipe terhadap berat kering total menunjukkan nilai yang berbeda pada tiap genotipenya. Genotipe P18, P27 dan P29 memiliki bobot kering tanaman lebih besar pada kondisi tanpa modifikasi kelembaban. Genotipe P7 lebih sensitif terhadap perlakuan. Hasil analisis dengan ANOVA pada taraf nyata $5 \%$ menunjukkan bahwa berat kering tanaman tidak berbeda nyata pada pengaruh perlakuan.

\section{Koefisien Pemadaman (k) dan Indeks Luas Daun (ILD)}

Boer dan Las (1994) menyatakan bahwa nilai koefisien pemadaman $(k)$ merupakan kemampuan tanaman dalam mengintersepsi radiasi surya. Nilai $k$ tidak terlalu berbeda antara tanaman kondisi tidak jenuh dan jenuh. Nilai k pada kondisi jenuh sedikit lebih besar dibandingkan kondisi tidak jenuh yaitu rata-rata sebesar 0.38 , sedangkan kondisi tidak jenuh ratarata sebesar 0.37. Tanaman yang memiliki daun tegak, nilai k berkisar antara 0.3-0.5 (Tabel 2). Secara teori, koefisien pemadaman berbanding terbalik dengan ILD, semakin besar nilai ILD maka koefisien pemadaman tajuk semaki kecil (Binkley et al., 2013).

Nilai ILD semakin meningkat seiring dengan bertambahnya umur tanaman. Nilai ILD maksimum untuk kedua perlakuan terjadi pada 7 MST, kemudian pada 8 MST besarnya nilai ILD tanaman melon tetap. Air yang tersedia cukup bagi tanaman sehingga daun-daun tanaman tidak perlu melakukan pengguguran daun untuk mengurangi bidang penguapan.

Tabel 2 Nilai koefisien pemadaman ( $k$ ) pada 12 genotipe tanaman melon dari kondisi tidak jenuh dan jenuh.

\begin{tabular}{ccc}
\hline \multirow{2}{*}{ Genotipe } & \multicolumn{2}{c}{ Koefesien Pemadaman $(\mathrm{k})$} \\
\cline { 2 - 3 } & Tanpa kelembaban & Modifikasi kelembaban \\
\hline P17 & 0.36 & 0.35 \\
P26 & 0.35 & 0.35 \\
P3 & 0.37 & 0.42 \\
P19 & 0.35 & 0.35 \\
P29 & 0.39 & 0.39 \\
P2 & 0.36 & 0.34 \\
P7 & 0.40 & 0.33 \\
P5 & 0.41 & 0.40 \\
P23 & 0.36 & 0.40 \\
P27 & 0.37 & 0.45 \\
P18 & 0.40 & 0.44 \\
P25 & 0.34 & 0.34 \\
\hline Rata-rata & 0.37 & 0.38 \\
\hline
\end{tabular}

Keterangan: kondisi saat 7 MST

ILD tanaman melon tertinggi pada kondisi tanpa modifikasi kelembaban diperoleh pada P25 sebesar $3.8 \mathrm{~cm}$ dan terendah pada P5 sebesar 3.2 cm (Gambar 2). Tanaman melon pada kondisi modifikasi kelembaban, besar ILD tertinggi terjadi pada P7 sebesar $3.9 \mathrm{~cm}$ dan yang terendah pada P27 sebesar $2.9 \mathrm{~cm}$ (Gambar 2). Nilai ILD ideal untuk tanaman melon adalah 3-5. Genotipe P7, P2, P18 dan P27 merupakan genotipe yang paling sensitif terhadap perlakuan. Genotipe P7 dan P2 akan menghasilkan yang lebih optimal apabila diberikan perlakuan kelembaban, sedangkan genotipe P18 dan P27 lebih optimal apabila tidak diberikan perlakuan.

\section{Intersepsi Radiasi}

Intersepsi radiasi oleh tanaman melon meningkat seiring pertambahan umur tanaman dan peningkatan ILD. Nilai intersepsi meningkat maksimum pada tanggal 19 hingga 25 September 2015 (4 MST) pada kedua perlakuan. Pada fase ini tanaman menjadi lebih lebat dan kanopi tanaman menjadi lebih lebar sehingga radiasi yang tertahan lebih besar dari yang ditransmisikan. 
Adinegara et. al./Agromet 31 (1): 31-42, 2017
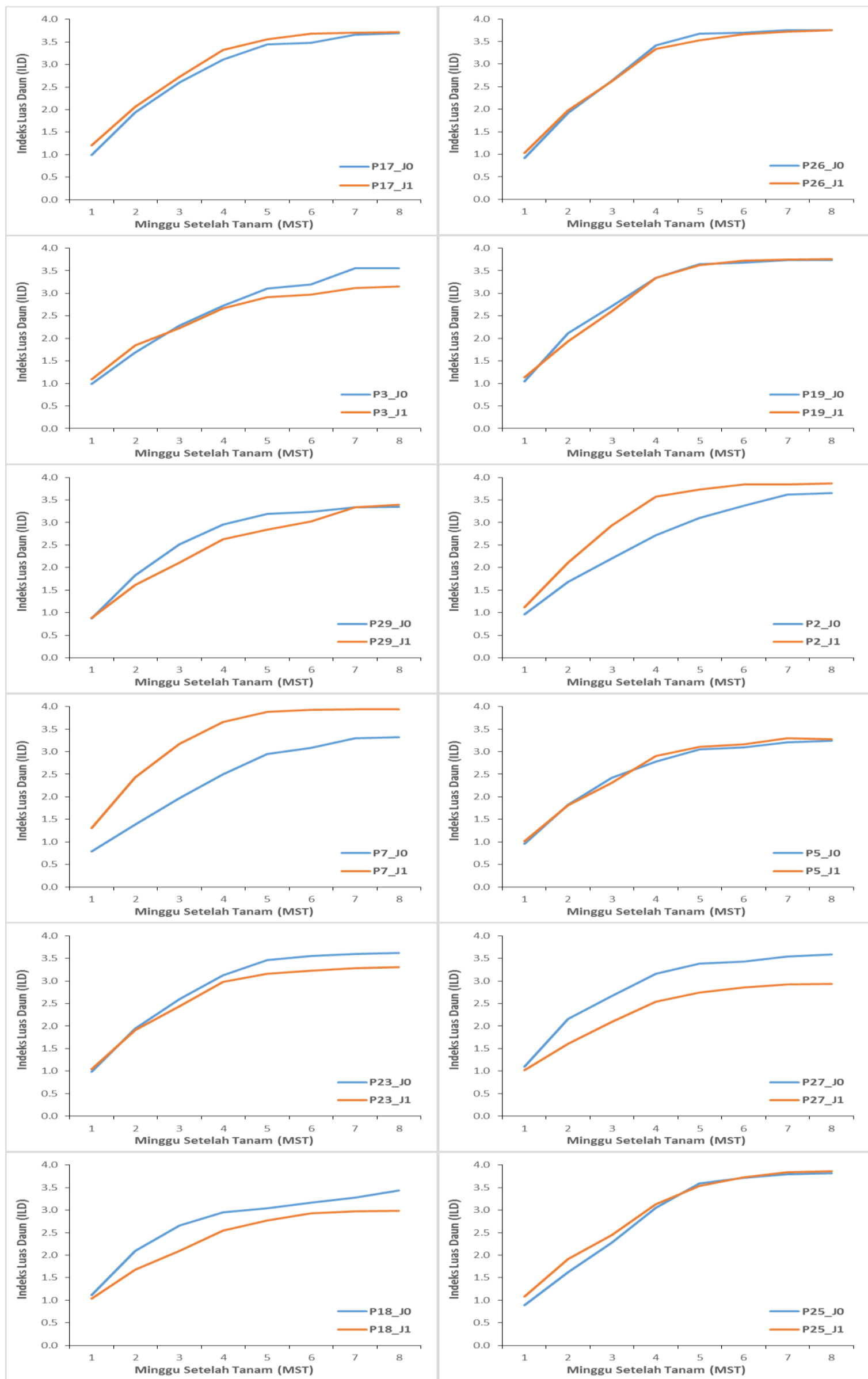

Gambar 2 Nilai ILD tanaman melon dari 12 genotipe pada kondisi tanpa modifikasi kelembaban dan kondisi modifikasi kelembaban. 
Pada tanggal 26 September hingga 2 November (5 MST) radiasi intersepsi menurun pada kedua perlakuan. Pada minggu tersebut radiasi rendah. Sehingga nilai intersepsi terhitung juga rendah. Koefisien pemadaman yang digunakan untuk menghitung nilai intersepsi radiasi sebesar 0.5 . Nilai ini diperoleh dari ratarata koefisien seluruh genotipe yang diuji pada kedua perlakuan.

Genotipe P25 memiliki nilai interepsi tertinggi pada kondisi tanpa modifikasi kelembaban yaitu sebesar $79.8 \mathrm{MJ} \mathrm{m}^{-2}$ minggu $^{-1}$ (Gambar 3). Selanjutnya nilai intersepsi tertinggi pada kondisi modifikasi kelembaban adalah genotipe P7 yaitu sebesar $80.7 \mathrm{~m}^{-2}$ minggu $^{-1}$ (Gambar 3). Nilai intersepsi tersebut diperoleh dengan menduga ILD harian. Peningkatan ILD tanaman hingga kondisi maksimum dapat mempengaruhi kapasitas fotosintesis tanaman untuk memproduksi berat kering karena kemampuan tajuk tanaman untuk mengintersepsi radiasi semakin meningkat.

Genotipe P7, P2, P18 dan P27 merupakan genotipe yang paling sensitif terhadap perlakuan. Genotipe P7 dan P2 apabila diberikan perlakuan modifikasi kelembaban akan menghasilkan nilai indeks luas daun yang lebih optimal, sehingga nilai intersepsi radiasi yang dihasilkan juga bernilai besar. Pada genotipe P18 dan P27 merupakan genotipe yang akan menghasilkan nilai intersepsi radiasi lebih optimal apabila tidak diberikan perlakuan.

\section{Efisiensi Pemanfaatan Radiasi Surya (EPR)}

Nilai efisiensi pemanfaatan radiasi surya (EPR) diperhitungkan dari hasil pembagian peningkatan bruto jumlah bahan kering yang diproduksi pada periode waktu tertentu dengan jumlah energi cahaya yang diintersepsi kanopi dalam periode waktu yang sama. Besarnya nilai akumulasi intersepsi radiasi surya akan berpengaruh terhadap jumlah bahan kering total yang dibentuk. Berdasarkan hasil penelitian, nilai EPR pada kedua perlakuan diperoleh nilai EPR berkisar diantara 1.2-1.7 g/MJ hasil tersebut sesuai dengan penelitian Kemanian et al. (2004) bahwa tanaman C3 (melon) semusim memiliki nilai EPR berkisar antara 1.2-1.7 g/MJ. Nilai EPR kondisi modifikasi kelembaban lebih besar dari kondisi tanpa modifikasi kelembaban yaitu ratarata sebesar 1.4 dan 1.3, (Tabel 3).

\section{Akumulasi Panas Tanaman Melon}

Waktu yang diperlukan oleh 12 tanaman genotipe yang diuji untuk satu siklus hidupnya relatif berbeda, dengan asumsi suhu dasar yang sama pada setiap genotipe yaitu sebesar $15^{\circ} \mathrm{C}$ (Baker and Reddy, 2001). Genotipe P3, P18 dan P25 pada kondisi modifikasi kelembaban merupakan genotipe dengan akumulasi panas lebih lama dari genotipe lain, yaitu sebesar $881^{\circ} \mathrm{C}$ hari (Tabel 4).

Tabel 3 Nilai efisiensi pemanfaatan radiasi (EPR) 12 genotipe tanaman melon dari kondisi tidak jenuh dan jenuh.

\begin{tabular}{ccc}
\hline \multirow{2}{*}{ Genotipe } & \multicolumn{2}{c}{ EPR $(\mathrm{g} / \mathrm{MJ})$} \\
\cline { 2 - 3 } & Tanpa kelembaban & Modifikasi kelembaban \\
\hline P17 & 1.2 & 1.6 \\
P26 & 1.3 & 1.6 \\
P3 & 1.4 & 1.3 \\
P19 & 1.0 & 1.6 \\
P29 & 1.0 & 1.4 \\
P2 & 1.7 & 1.4 \\
P7 & 0.9 & 1.8 \\
P5 & 1.2 & 1.4 \\
P23 & 0.9 & 1.6 \\
P27 & 1.5 & 1.0 \\
P18 & 1.5 & 1.2 \\
P25 & 1.9 & 1.2 \\
\hline Rata-rata & 1.3 & 1.4 \\
\hline
\end{tabular}

Keterangan: Huruf bercetak tebal menandakan genotipe memiliki nilai EPR tertinggi kondisi tanpa modifikasi kelembaban. Huruf yand digaris bawahi menandakan genotipe memiliki nilai EPR tertinggi kondisi modifikasi kelembaban. 
Adinegara et. al./Agromet 31 (1): 31-42, 2017
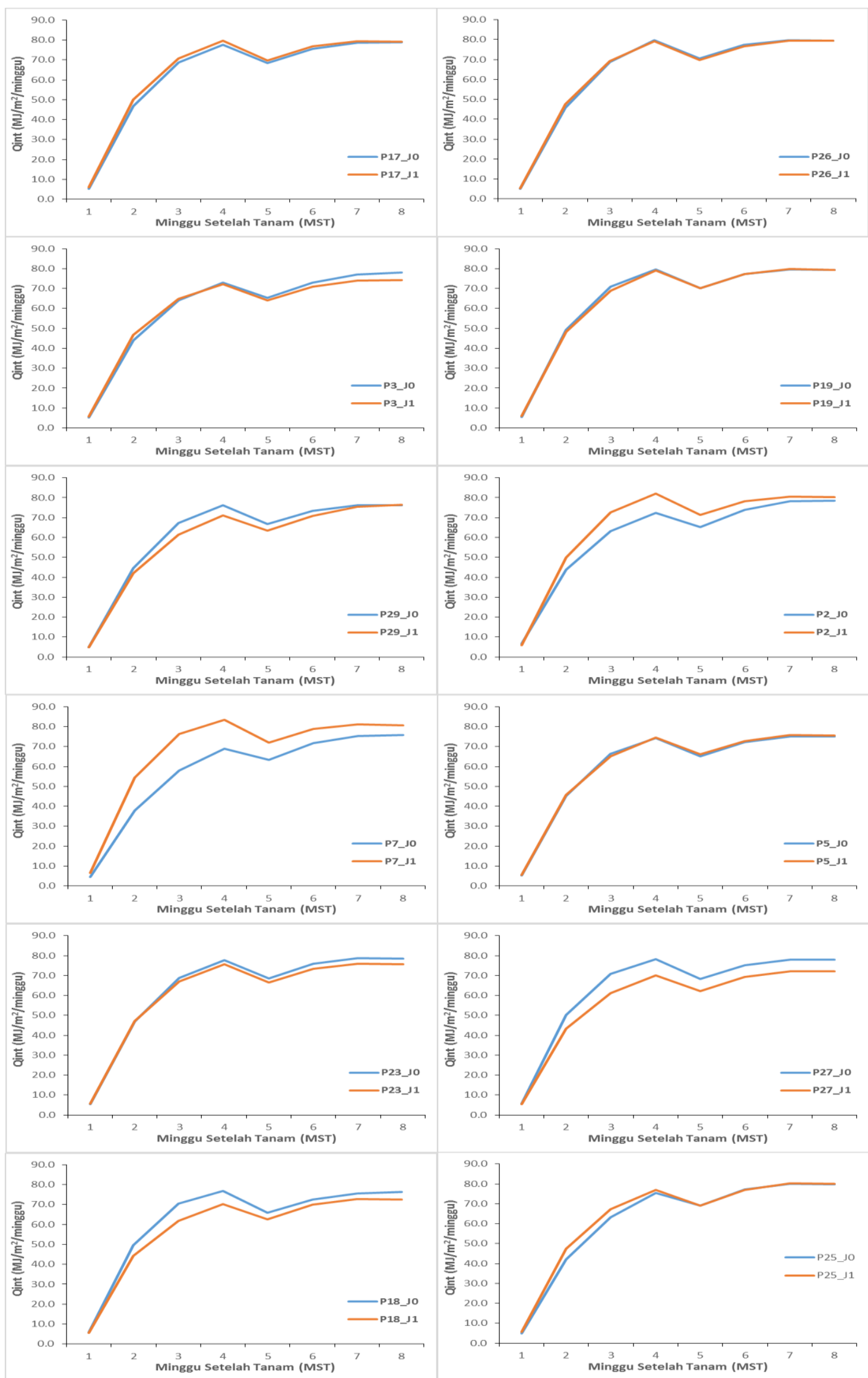

Gambar 3 Nilai radiasi intersepsi dari 12 genotipe pada kondisi tanpa modifikasi kelembaban dan kondisi modifikasi kelembaban. 
Tabel 4 Akumulasi Panas dari 12 genotipe hingga panen pada kondisi tanpa modifikasi kelembaban dan kondisi modifikasi kelembaban.

\begin{tabular}{cccccccccccc}
\hline \multicolumn{10}{c}{ Akumulasi Panas Kondisi Tanpa Modifikasi Kelembaban $\left({ }^{\circ} \mathrm{C}\right.$ hari $)$} \\
\hline P17 & P26 & P3 & P19 & P29 & P2 & P7 & P5 & P23 & P27 & P18 & P25 \\
\hline \multicolumn{8}{c}{ Akumulasi Panas Kondisi Modifikasi Kelembaban $\left({ }^{\circ} \mathrm{C}\right.$ hari $)$} \\
\hline P17 & P26 & P3 & P19 & P29 & P2 & P7 & P5 & P23 & P27 & P18 & P25 \\
\hline 850 & 815 & 881 & 815 & 850 & 850 & 792 & 768 & 850 & 815 & 881 & 881 \\
\hline \multicolumn{7}{l}{ Keterangan: Kolom yang diberikan warna kuning menandakan genotipe tersebut mati. }
\end{tabular}

\section{Bobot Buah Tanaman Melon}

Genotipe melon tanpa modifikasi kelembaban mengalami waktu panen yang lebih pendek atau akumulasi panas yang lebih sedikit dari kondisi modifikasi kelembaban yaitu berkisar antara 61-63 HST, sedangkan untuk genotipe dengan modifikasi kelembaban waktu panen antara 68-71 HST. Pada kondisi modifikasi kelembaban cenderung memiliki bobot buah lebih besar dari kondisi tanpa modifikasi kelembaban yaitu rata-rata bobot buah kondisi modifikasi kelembaban dan tanpa modifikasi kelembaban berturut-turut sebesar $1,209 \mathrm{~g}$ dan $1,118 \mathrm{~g}$ hal ini disebabkan karena umur tanaman melon dengan modifikasi kelembaban lebih panjang dari kondisi tanpa modifikasi kelembaban, sehingga akumulasi hasil fotosintesis pada buah lebih besar.

Pada kondisi tanpa modifikasi kelembaban banyak tanaman yang tidak berhasil berproduksi karena busuk buah, hal ini terjadi pada semua genotipe tanaman melon yang ditanam.
Genotipe P17 dan P5 kondisi tanpa modifikasi kelembaban, semua tanaman yang diuji mati dan busuk buah (Gambar 4).

Genotipe P19 dan P7 merupakan genotipe yang paling sensitif terhadap perlakuan modifikasi kelembaban yang menunjukkan hasil lebih optimal apabila diberikan perlakuan. Genotipe P19 memiliki bentuk buah globulardan memiliki kulit dan daging berwarna putih dengan tingkat kemanisan rata-rata 9.3. Genotipe P19 memberikan hasil tertinggi pada kondisi modifikasi kelembaban. Genotipe P27 dan P18 merupakan genotipe yang lebih tahan dan berproduksi lebih baik pada kondisi lebih kering. Genotipe P27 memiliki bentuk buah ellips dan memiliki kulit berwarna oranye dan daging berwarna kuning degan tingkat kemanisan ratarata 8.8. Genotipe P18 memiliki bentuk buah ellips dan memiliki kulit kuning dan daging putih dengan tingkat kemanisan 8.5. Genotipe P19, P7, P27 dan P18 merupakan genotipe yang tidak memiliki jala dan buah non-klimaterik.

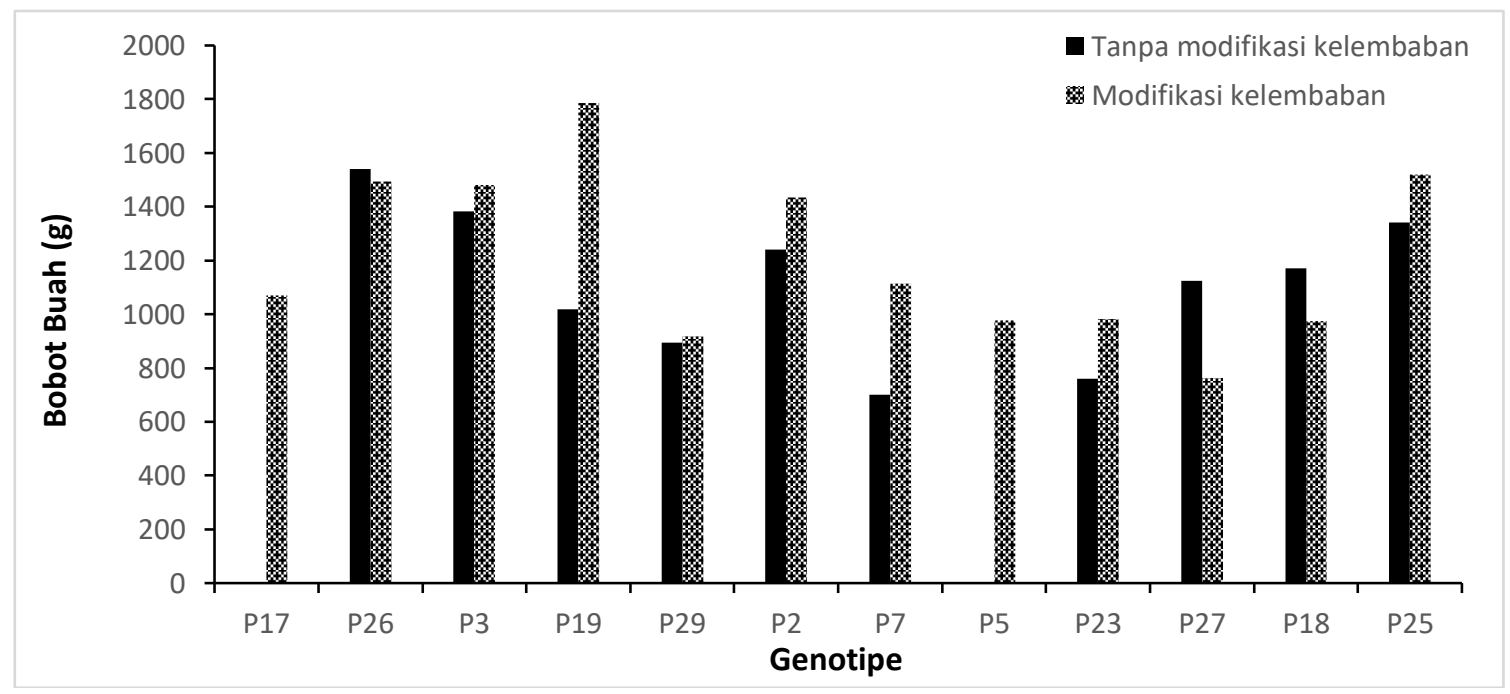

Gambar 4 Hasil panen dari 12 tanaman melon contoh yang diuji tanpa modifikasi kelembaban dan kondisi modifikasi kelmbaban. 


\section{KESIMPULAN}

Pertumbuhan tanaman melon tidak optimal pada ruang semai tanpa modifikasi kelembaban. Hasil penelitian menunjukkan bahwa kondisi tanpa modifikasi kelembaban menyebabkan laju transpirasi atau penggunaan air lebih rendah. Kekurangan air cenderung menghambat pertumbuhan dan menurunkan produksi tanaman melon. Pada fase perkecambahan, perlakuan berpengaruh pada tinggi tanaman genotipe P17, P26, P3, P29, P2, P23 dan P25.

Indeks luas daun (ILD) pada 12 tanaman melon yang diuji tidak terpengaruh oleh perlakuan, hal serupa juga ditemukan pada nilai intersepsi radiasi matahari. Peningkatan ILD dapat meningkatkan intersepsi radiasi matahari. Genotipe P7, P2, P18 dan P27 merupakan genotipe yang paling sensitif terhadap perlakuan. Genotipe P25 pada kondisi tanpa modifikasi kelembaban dan P7 pada kondisi modifikasi kelembaban lebih efisien dalam pemanfaatan radiasi surya dibandingkan genotipe tanaman melon lainnya (1.9 dan $1.8 \mathrm{~g} \mathrm{MJ}^{-1}$ ). Akumulasi panas pada kondisi modifikasi kelembaban dari 12 genotipe lebih besar dari kondisi tanpa modifikasi kelembaban. Genotipe P3, P18 dan P25 pada kondisi modifikasi kelembaban merupakan genotipe dengan akumulasi panas lebih besar dari genotipe lainnya $\left(881^{\circ} \mathrm{C}\right.$ hari).

Genotipe pada kondisi tanpa modifikasi kelembaban memiliki umur panen yang lebih pendek (61-63 HST) dan bobot buah lebih rendah $(1,118 \mathrm{~g})$. Genotipe pada kondisi modifikasi kelembaban (68-71 HST) memiliki umur panen lebih panjang dan bobot buah lebih tinggi, (1,209 g). Genotipe P19, P7, P27 dan P18 merupakan genotipe yang sensitif terhadap perlakuan serta genotipe tersebut tidak memiliki jala dan buah non-klimaterik. Genotipe P19 memberikan hasil tertinggi pada kondisi modifikasi kelembaban. Genotipe P27 dan P18 merupakan genotipe yang lebih tahan terhadap kondisi kering dan berproduksi lebih baik tanpa modifikasi kelembaban.

\section{DAFTAR PUSTAKA}

Arifin, B., 2013. On the Competitiveness and Sustainability of the Indonesian
Agricultural Export Commodities. ASEAN Journal of Economic, Management and Accounting 1, 81-100.

Baker, J.T., Reddy, V.R., 2001. Temperature Effects on Phenological Development and Yield of Muskmelon. Annals of Botany 87, 605613.

https://doi.org/10.1006/anbo.2001.1381

Binkley, D., Campoe, O.C., Gspaltl, M., Forrester, D.I., 2013. Light absorption and use efficiency in forests: Why patterns differ for trees and stands. Forest Ecology and Management 288, 5-13. https://doi.org/10.1016/j.foreco.2011.11. 002

Boer, R., Las, I., 1994. Koefisien Pemadaman Tanaman Kedele Pada Beberapa Tingkat Radiasi. Jurnal Agromet 10, 29-34.

Claeys, H., Inzé, D., 2013. The Agony of Choice: How Plants Balance Growth and Survival under Water-Limiting Conditions. Plant Physiol. 162, 1768. https://doi.org/10.1104/pp.113.220921

Cleland, E.E., Chuine, I., Menzel, A., Mooney, H.A., Schwartz, M.D., 2007. Shifting plant phenology in response to global change. Trends in Ecology \& Evolution 22, 357365.

https://doi.org/10.1016/j.tree.2007.04.00 3

Ditjenhorti, 2014. Statistik Produksi Hortikultura Tahun 2013.

Falah, M., Khuriyati, N., Safitri, R., Revulaningtyas, I., 2014. Quality evaluation of fresh and fresh-cut melon (Cucumis melo, L) fruit in a tropical environment. Journal of Agricultural Technology 10, 1201-1211.

Hatfield, J.L., Prueger, J.H., 2015. Temperature extremes: Effect on plant growth and development. Weather and Climate Extremes 10, 4-10. https://doi.org/10.1016/j.wace.2015.08.00 1

Hutabarat, B., Setiyanto, A., Kustiari, R., Sulser, T., 2012. Conjecturing Production, Imports And Consumption Of Horticulture In Indonesia In 2050: A Gams Simulation Through Changes In Yields Induced By 
Climate Change. Jurnal Agro Ekonomi 30, 1-23.

Irmak, S., O. Odhiambo, L., E. Specht, J., Djaman, K., 2013. Hourly and Daily Single and Basal Evapotranspiration Crop Coefficients as a Function of Growing Degree Days, Days After Emergence, Leaf Area Index, Fractional Green Canopy Cover, and Plant Phenology for Soybean. Transactions of the ASABE 56, 1785-1803. https://doi.org/10.13031/trans.56.10219

J. Lipiec, C. Doussan, A. Nosalewicz, K. Kondracka, 2013. Effect of drought and heat stresses on plant growth and yield: a review. International Agrophysics 27, 463-477. https://doi.org/10.2478/intag-2013-0017

Kataria, S., Jajoo, A., Guruprasad, K.N., 2014. Impact of increasing Ultraviolet-B (UV-B) radiation on photosynthetic processes. Journal of Photochemistry and Photobiology B: Biology 137, 55-66. https://doi.org/10.1016/j.jphotobiol.2014. 02.004

Kemanian, A.R., Stöckle, C.O., Huggins, D.R., 2004. Variability of Barley Radiation-Use Efficiency. Crop Science 44, 1662-1672. https://doi.org/10.2135/cropsci2004.1662

Killi, D., Anlauf, R., Kavdir, Y., Haworth, M., 2014. Assessing the impact of agro-industrial olive wastes in soil water retention: Implications for remediation of degraded soils and water availability for plant growth. International Biodeterioration \& Biodegradation $\quad 94, \quad 48-56$. https://doi.org/10.1016/j.ibiod.2014.06.01 9

Körner, C., 2015. Paradigm shift in plant growth control. Current Opinion in Plant Biology 25 , 107-114. https://doi.org/10.1016/j.pbi.2015.05.003

Molitor, D., Junk, J., Evers, D., Hoffmann, L., Beyer, M., 2014. A High-Resolution Cumulative Degree Day-Based Model to Simulate Phenological Development of Grapevine. Am. J. Enol. Vitic. 65, 72. https://doi.org/10.5344/ajev.2013.13066

Moshelion, M., HALPERIN, O., WALLACH, R., OREN, R., WAY, D.A., 2014. Role of aquaporins in determining transpiration and photosynthesis in water-stressed plants: crop water-use efficiency, growth and yield. Plant, Cell \& Environment 38, 1785-1793. https://doi.org/10.1111/pce.12410

Nashih, A., Widodo, K., Ismoyowati, D., 2016. Inventory Level Analysis of Horticultural Commodities Exported by PT BSL from Central Java Indonesia to Singapore. KnowledgeE Life Sciences 129-132. http://dx.doi.org/10.18502/kls.v3i3.407D OI: $10.18502 / k l s . v 3 i 3.407$

Ren, Y., Bang, H., Gould, J., Rathore, K.S., Patil, B.S., Crosby, K.M., 2013. Shoot regeneration and ploidy variation in tissue culture of honeydew melon (Cucumis melo L. inodorus). In Vitro Cellular \& Developmental Biology - Plant 49, 223 229. https://doi.org/10.1007/s11627-0129482-8

Sánchez, B., Rasmussen, A., Porter, J.R., 2013. Temperatures and the growth and development of maize and rice: a review. Global Change Biology 20, 408-417. https://doi.org/10.1111/gcb.12389

Sharma, S.P., Leskovar, D.I., Crosby, K.M., Volder, A., Ibrahim, A.M.H., 2014. Root growth, yield, and fruit quality responses of reticulatus and inodorus melons (Cucumis melo L.) to deficit subsurface drip irrigation. Agricultural Water Management 136, 75-85. https://doi.org/10.1016/j.agwat.2014.01.0 08

Silveira, A.C., Aguayo, E., Artés, F., 2013. The suitability of three Galia melon cultivars and different types of cuts for the freshcut industry. Journal of the Science of Food and Agriculture 93, 3826-3831. https://doi.org/10.1002/jsfa.6306

Singh, R.P., Prasad, P.V.V., Reddy, K.R., 2013. Chapter Two - Impacts of Changing Climate and Climate Variability on Seed Production and Seed Industry, in: Sparks, D.L. (Ed.), Advances in Agronomy. Academic Press, pp. 49-110. https://doi.org/10.1016/B978-0-12405942-9.00002-5 
Adinegara et. al./Agromet 31 (1): 31-42, 2017

Yekti, A., Darwanto, D., Jamhari, Hartono, S., 2015.

Approach (SFA). International Journal of Technical Efficiency of Melon Farming in Computer Applications 132, 15-19.

Kulon Progo: A Stochastic Frontier 